\title{
FENTON-LIKE OXIDATION OF FLEXOGRAPHIC WATER-BASED KEY (BLACK) DYE: A DEFINITIVE SCREENING DESIGN OPTIMIZATION
}

\author{
Vesna Gvoić ${ }^{1}$ (D), Miljana Prica ${ }^{1}$ (D), Đurđa Kerkez 2 (D), Ognjan Lužanin ${ }^{3}$ (D), \\ Aleksandra Kulić Mandić ${ }^{2}$ (D), Milena Bečelić-Tomin ${ }^{2}$ (D), Dragana Tomašević Pilipović ${ }^{2}$ (iD) \\ ${ }^{1}$ University of Novi Sad, Faculty of Technical Sciences, \\ Department of Graphic Engineering and Design, Novi Sad, Serbia \\ ${ }^{2}$ University of Novi Sad, Faculty of Sciences, \\ Department of Chemistry, Biochemistry and Environmental Protection, Novi Sad, Serbia \\ ${ }^{3}$ University of Novi Sad, Faculty of Technical Sciences, \\ Department of Production Engineering, Novi Sad, Serbia
}

\begin{abstract}
Fenton oxidation process has obtained large applicative use for efficient water remediation, whereby overall reaction efficiency could be improved by developing advanced Fenton catalysts. In order to synthesize iron nanoparticles with higher catalytic activity, a simple and eco-friendly method using $\mathrm{FeCl}_{3}$ and aqueous plant extract (oak leaves) was applied in this paper. The nano zero valent iron particles were used as a catalyst in Fenton treatment to remove organic dye from aqueous solution. The objective of this study was to optimize Fenton-like process for the removal of black printing dye using a recently developed design of experiment method - definitive screening design. This novel design framework significantly reduces the number of experiments required to estimate the model parameters and to establish the optimum operation conditions. The experiments were carried out in a batch mode technique, investigating the influence of dye concentration (20 - $\left.180 \mathrm{mgL}^{-1}\right)$, nanoparticles dosage $\left(0.75-60 \mathrm{mgL}^{-1}\right), \mathrm{H}_{2} \mathrm{O}_{2}$ concentration (1 - $11 \mathrm{mM})$ and $\mathrm{pH}$ value of the solution (2 - 10) on the decolorization efficiency. The Fenton-like process resulted with $79 \%$ of dye removal from aqueous solution under the optimal process conditions: dye concentration of $180 \mathrm{mgL}^{-1}$, nanoparticles dosage of $0.75 \mathrm{mgL}^{-1}, \mathrm{H}_{2} \mathrm{O}_{2}$ concentration of 1 $\mathrm{mM}$ and $\mathrm{pH}$ of 2. Increasing the $\mathrm{pH}$ value to slightly acidic or near neutral (5-7) medium resulted with slight decrease in the process efficiency (69.14 -62.63\%), but a limitation in the form of sludge generation is noticeable.
\end{abstract}

Key words: definitive screening design, optimization, printing dye removal, Fenton-like process, iron nanoparticles

\section{INTRODUCTION}

Synthetic dyes and pigments are widely used in printing, pharmaceutical, textile, leather and other industries. As a result, the industrial effluents are loaded with residual dyes and easily find their way into public waterways (Noreen et al, 2020). Wastewaters generated after the printing process are enriched with dyes, solvents (dioxins, dibenzofurans, pesticides, polychlorinated biphenyls, acids, bases), heavy metals, surfactants, additives, categorized as highly hazardous and toxic substances (Natarajan et al, 2018). Therefore, printing wastewaters are characterized with high $\mathrm{pH}$ value, temperature and conductivity, high content of suspended solids and total organic carbon (TOC), high values of chemical oxygen demand (COD), but low values of biological oxygen demand (BOD), where low BOD/COD ratio implies to high content of non-biodegradable organic matter (Tung et al, 2013; Natarajan et al, 2018; Zhu et al, 2018). More than $80 \%$ of the global demand for synthetic dyes is directed to azo dyes production, which are mostly used for dyeing of paper, leather textiles and plastics. These dyes represent heterocyclic systems with chromophore azo group $(-\mathrm{N}=\mathrm{N}-)$ bond to the $\mathrm{sp}^{2}$ carbon atoms of the aromatic rings. They are soluble in water, showing high stability at different $\mathrm{pH}$ values, high temperatures and brightness (Kong et al, 2018; Srinivasan and Sadasivam, 2018).

Numerous studies have been conducted in the field of wastewater treatment and dye removal. Researchers suggest that the ideal treatment should provide efficient removal of high dyes concentration in a short period of time without creating secondary contamination, whereby treated wastewater could be reused (Galiano et al, 2018; Maučec et al, 2018; Wang et al, 2019b). However, a difference must be made when defining the terms of treated wastewater decolorization and dye molecules degradation. Decolorization implies to the reduction of initial dye concentration, whereby the treated wastewater may still be rich with organic matter. When the process of dye removal is accompanied by COD and TOC 
reduction, a dye degradation phenomenon is conducted (Collivignarelli et al, 2015; Massoudinejad et al, 2015). Studies indicate that there is no single method that can be applied to all types of dyed effluents, whereby both type of industry that generates wastewater and the pronounced variability of the dye nature must be taken into account (Collivignarelli et al, 2019). Many studies have recently been conducted using advanced oxidation processes (AOPs) to degrade organic pollutants including $\mathrm{UV} / \mathrm{H}_{2} \mathrm{O}_{2}$ (Ramos et al, 2020), UV/TiO 2 (Sriprom et al, 2019), and homogeneous or heterogeneous Fenton processes (Sreeja and Sosamony, 2016). The application of nanozerovalent (nZVI) particles in Fenton-like process for degradation of wide range of organic substances has achieved certain advantages over conventional methods and solved their practical disadvantages, such as application of iron in high concentrations, sludge generation in a form of metal hydroxide after treatment, work in a narrow $\mathrm{pH}$ range, as well as the regeneration of the catalyst and the impossibility of its reuse. Due to the properties and surface of nanomaterials, numerous studies have proven the success of nZVI particles application as Fenton catalyst (Mukherjee et al, 2016; Chen et al, 2017; Pirsaheb et al, 2019).

Process optimization is crucial to enhance the efficiency of applied treatment. This paper aims to investigate and examine the impact of Fenton-like process conditions (dye concentration, nanoparticles dosage, $\mathrm{pH}$ and $\mathrm{H}_{2} \mathrm{O}_{2}$ concentration) for black printing dye degradation, by using a novel statistical approach - definitive screening design (DSD).

\section{MATERIALS AND METHODS}

\subsection{Reagents}

In the present study, degradation of black water-soluble flexographic printing dye (Flint group, CAS number: 1064-48-8; color index: PK7; molecular weight: 616.49 gmol$^{-1}$; absorption wavelength: $613 \mathrm{~nm}$ ), is studied. Black printing dye poses two azo $(-\mathrm{N}=\mathrm{N}-)$ groups in its structure (figure 1$)$ and belongs to the group of diazo dyes. The presence of the $\pi$-bond in the azo group makes it a desirable site of attack for hydroxyl $\left(\mathrm{HO}^{*}\right)$ radicals in advanced oxidation processes. (Meetani et al, 2010).

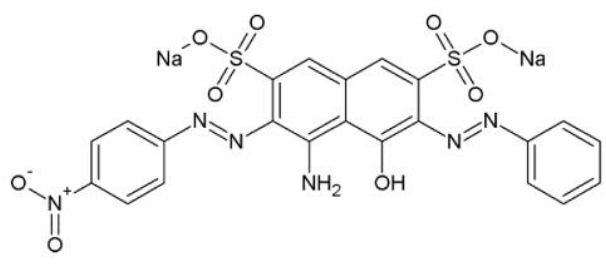

Figure 1: Chemical structure of black printing dye

Sample of wastewater was obtained from one flexographic printing facility in Novi Sad. Aqueous dye solution was prepared by dissolving appropriate amounts of black dye with deionized water to the desired concentration.

nZVI particles, as Fenton catalyst, were synthesized according to the previous report through the "green" synthesis method (Machado et al, 2013; Kecić et al, 2018).

Hydrogen peroxide, 30\% (NRK Engineering, Serbia), sodium hydroxide, >98.8\% (POCH), $\mathrm{CcH}_{2} \mathrm{SO}_{4},>96 \%$ (J.T. Baker) were of analytical grade and used without any further purification.

\subsection{Experimental procedure}

The degradation process of black dye was carried out in a $500 \mathrm{~mL}$ glass beaker containing $250 \mathrm{~mL}$ dye solution (Kecić et al, 2018). Various concentrations of $\mathrm{nZVI}\left(0.75-60 \mathrm{mgL}^{-1}\right)$ and $\mathrm{H}_{2} \mathrm{O}_{2}(1-10 \mathrm{mM})$ were mixed with the solution, whereby $\mathrm{pH}$ value was adjusted using $0.1 \mathrm{M} \mathrm{ccH}_{2} \mathrm{SO}_{4}$ and $\mathrm{NaOH}$. All reaction systems were mixed on a JAR apparatus (FC6S Velp Scientific, Italy) at $120 \mathrm{rpm}$ and constant temperature of $23{ }^{\circ} \mathrm{C}$. The residual dye concentration was established immediately by measuring the absorbance of the aqueous solutions at $613 \mathrm{~nm}$ with UV/VIS spectrophotometer (UV-1800 PG Instruments Ltd T80+ UV/VIS, Japan). Dye removal efficiency was calculated using the equation (1):

$E(\%)=A_{0}-A / A_{0} * 100$ 
where the $A_{0}$ indicates the absorption of dye before Fenton-like treatment and $A$ indicates the dye absorption after the treatment.

\subsection{Statistical analysis}

The DSD platform was utilized to evaluate the main and interaction effects of the Fenton-like process's parameters on the decolorization efficiency. The experimental design was built around four factors, each having three levels representing the low (-), central (0), and high (+), with the addition of two central points. The factors and corresponding operating conditions are: dye concentration (20 $\mathrm{mgL}^{-1}, 100 \mathrm{mgL}^{-1}$, $\left.180 \mathrm{mgL}^{-1}\right), \mathrm{nZVI}$ dosage $\left(0.75 \mathrm{mgL}^{-1}, 30 \mathrm{mgL}^{-1}\right.$ and $\left.60 \mathrm{mgL}^{-1}\right), \mathrm{H}_{2} \mathrm{O}_{2}$ concentration ( $1 \mathrm{mM}, 5 \mathrm{mM}$ and 10 $\mathrm{mM}$ ) and $\mathrm{pH}$ value (2, 6 and 10). A randomized experimental sequence was followed and the obtained values for the decolorization efficiency (\%) were obtained (Felix et al, 2019; Zhao et al, 2019). JMP 13 software was used for the statistical analysis.

\section{RESULTS AND DISCUSSIONS}

\subsection{Model fitting}

Using the fitted full quadratic model, a response surface regression analysis for decolorization efficiency was performed. It contained a total of 28 terms with four input factors, including the main effects and two-way interaction terms. Table 1 presents the results of black dye decolorization efficiency with the yields of $0.43-88.86 \%$. The models were fit using a forward stepwise JMP's regression analysis, while the results are presented through summary of fit (Table 2), ANOVA table (Table 3), parameter estimates (Table 4), surface plot (Figure 2) and optimization plots (Figure 3).

Table 1: DSD matrix and obtained decolorization efficiency

\begin{tabular}{|c|c|c|c|c|c|}
\hline No. & $\begin{array}{l}\text { Dye concentration } \\
\qquad\left(\mathrm{mgL}^{-1}\right)\end{array}$ & $\begin{array}{l}\text { nZVI dosage } \\
\left(\mathrm{mgL}^{-1}\right)\end{array}$ & $\mathrm{pH}$ & $\begin{array}{c}\mathrm{H}_{2} \mathrm{O}_{2} \text { concentration } \\
(\mathrm{mM})\end{array}$ & $\begin{array}{l}\text { Decolorization } \\
\text { efficiency (\%) }\end{array}$ \\
\hline 1 & 180 & 0.75 & 10 & 11 & 2.96 \\
\hline 2 & 20 & 30.375 & 2 & 11 & 10 \\
\hline 3 & 180 & 60 & 2 & 11 & 44.08 \\
\hline 4 & 20 & 60 & 10 & 6 & 1.11 \\
\hline 5 & 100 & 60 & 10 & 11 & 0.46 \\
\hline 6 & 20 & 0.75 & 10 & 1 & 2.22 \\
\hline 7 & 20 & 60 & 2 & 1 & 11.11 \\
\hline 8 & 180 & 0.75 & 2 & 6 & 47.99 \\
\hline 9 & 100 & 30.375 & 6 & 6 & 42.01 \\
\hline 10 & 180 & 60 & 6 & 1 & 88.86 \\
\hline 11 & 100 & 0.75 & 2 & 1 & 54.79 \\
\hline 12 & 180 & 30.375 & 10 & 1 & 49.53 \\
\hline 13 & 20 & 0.75 & 6 & 11 & 1.11 \\
\hline 14 & 180 & 0.75 & 10 & 11 & 2.42 \\
\hline 15 & 20 & 30.375 & 2 & 11 & 36.7 \\
\hline 16 & 180 & 60 & 2 & 11 & 45.28 \\
\hline 17 & 20 & 60 & 10 & 6 & 1.83 \\
\hline 18 & 100 & 60 & 10 & 11 & 0.43 \\
\hline 19 & 20 & 0.75 & 10 & 1 & 0.92 \\
\hline 20 & 20 & 60 & 2 & 1 & 12.84 \\
\hline 21 & 180 & 0.75 & 2 & 6 & 56.87 \\
\hline 22 & 100 & 30.375 & 6 & 6 & 40.18 \\
\hline 23 & 180 & 60 & 6 & 1 & 18.32 \\
\hline 24 & 100 & 0.75 & 2 & 1 & 47.03 \\
\hline 25 & 180 & 30.375 & 10 & 1 & 44.59 \\
\hline 26 & 20 & 0.75 & 6 & 11 & 2.22 \\
\hline 27 & 100 & 30.375 & 6 & 6 & 25.8 \\
\hline 28 & 100 & 30.375 & 6 & 6 & 18.55 \\
\hline
\end{tabular}


Descriptive factors for selected statistical model that best approximate the experimental data are shown in Table 2. The adopted regression model explains approximately 84 per cent of variance in the observed experiments. Although the correlation factor $\left(R^{2}=0.834\right)$ was characterized with low level, the result of ANOVA test (Table 3 ) indicates that regression model is highly significant $(F<0.0001)$, while the validity of selected model is confirmed based on the "lack of fitness" test ( $\mathrm{P}>0.05)$.

Table 2: Summary of fit

\begin{tabular}{|l|c|}
\hline Descriptive factor & Value \\
\hline RSquare & 0.834 \\
\hline RSquare Adj & 0.750 \\
\hline AIC & 244.730 \\
\hline BIC & 242.880 \\
\hline Root Mean Square Error & 11.997 \\
\hline
\end{tabular}

Table 3: ANOVA and lack of fit test

\begin{tabular}{|c|c|c|c|c|}
\hline Source & ${ }^{\mathrm{a} D F}$ & bSS & ${ }^{\mathrm{c} M S}$ & F parameter \\
\hline Model & 9 & 12968.554 & 1440.950 & 10.012 \\
\hline Error & 18 & 2590.494 & 143.920 & Prob $>\mathrm{F}$ \\
\hline C. Total & 27 & 15559.048 & - & $<0.0001$ \\
\hline Lack of Fit & 16 & 2348.093 & 146.756 & 1.211 \\
\hline Pure Error & 2 & 242.401 & 121.201 & Prob $>\mathrm{F}$ \\
\hline Total Error & 18 & 2590.494 & - & 0.544 \\
\hline
\end{tabular}

aDegrees of freedom, bSum of squares, cMean square

Based on the estimated regression coefficients (Table 4), it can be noticed that the dye concentration and $\mathrm{pH}$ value achieve the greatest impact on the Fenton process efficiency. Although both statistically significant, dye and $\mathrm{H}_{2} \mathrm{O}_{2}$ concentration are a part of a statistically significant interaction (Figure 2). Its interaction plot shows that maximum decolorization efficiency is obtained for $\mathrm{H}_{2} \mathrm{O}_{2}$ concentration at lowest level $(1 \mathrm{mM})$, and dye concentration at highest level $\left(180 \mathrm{mgL}^{-1}\right)$.

Table 4: Parameter estimates

\begin{tabular}{|l|c|c|c|c|}
\hline Parameter & Estimate & Standard Error & $t$ value & Prob $>|\mathrm{t}|$ \\
\hline Dye $\left(\mathrm{mgL}^{-1}\right)$ & 16.042 & 2.6825 & 5.98 & $<0.0001$ \\
\hline $\mathrm{pH}$ & -13.011 & 2.6825 & -4.85 & 0.0001 \\
\hline $\mathrm{H}_{2} \mathrm{O}_{2}(\mathrm{mM})$ & -9.228 & 2.6825 & -3.44 & 0.0029 \\
\hline Dye ${ }^{*} \mathrm{H}_{2} \mathrm{O}_{2}$ & -9.553 & 3.0975 & -3.09 & 0.0064 \\
\hline $\mathrm{nZVI}{ }^{*} \mathrm{H}_{2} \mathrm{O}_{2}$ & 5.850 & 3.0975 & 1.89 & 0.0752 \\
\hline $\mathrm{nZVI}\left(\mathrm{mgL}^{-1}\right)$ & 0.299 & 2.6825 & 0.11 & 0.9153 \\
\hline
\end{tabular}

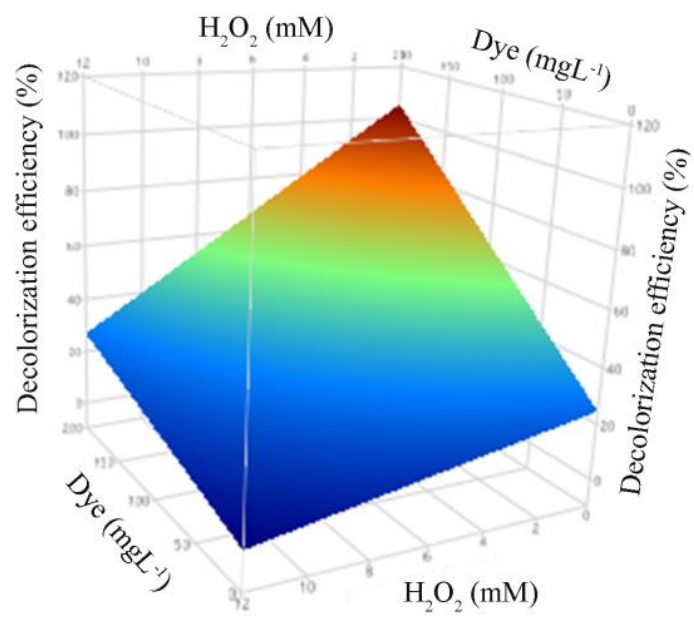

Figure 2: Surface plot showing the interaction effects between dye and $\mathrm{H}_{2} \mathrm{O}_{2}$ concentration 
Within the $\mathrm{nZVI} / \mathrm{H}_{2} \mathrm{O}_{2}$ Fenton treatment, statistical software proposes a maximum decolorization efficiency of $78.89 \%$ within the following optimum process conditions (Figure 3a): dye concentration of $180 \mathrm{mgL}^{-1}, \mathrm{nZVI}$ dosage of $0.75 \mathrm{mgL}^{-1}, \mathrm{H}_{2} \mathrm{O}_{2}$ concentration of $1 \mathrm{mM}$ and $\mathrm{pH}$ value 2 . However, the $\mathrm{pH}$ value 2 is unfavorable from the environmental aspect: experiment requires the consumption of large amounts of chemicals in order to acidify the treated medium and subsequent neutralization of the effluent before its release into the recipient is required.

Figure $3 \mathrm{~b}$ shows the modified optimal process conditions, whereby it was found that increased $\mathrm{pH}$ value slightly reduces the decolorization efficiency of the synthetic black dye solution. Namely, with the $\mathrm{pH}$ values increase to 5, 6 and 7, the efficiency of $\mathrm{nZVI} / \mathrm{H}_{2} \mathrm{O}_{2}$ Fenton process decreased from $79 \%$ to $69.14 \%$, $65.89 \%$ and $62.63 \%$, respectively. Taking into account the environmental aspects and the potential negative impact of the release of highly acidic effluents into the recipients, the researcher is offered the opportunity to choose a more favorable process. In this case it can be a process optimized to $\mathrm{pH} 7$, but a limitation in a sludge formation in neutral environment is noticeable. This observation implies that a $\mathrm{nZVI} / \mathrm{H}_{2} \mathrm{O}_{2}$ Fenton process is more favorable and cost effective in acidic medium then in neutral, which would have to be accompanied by additional sludge treatment.

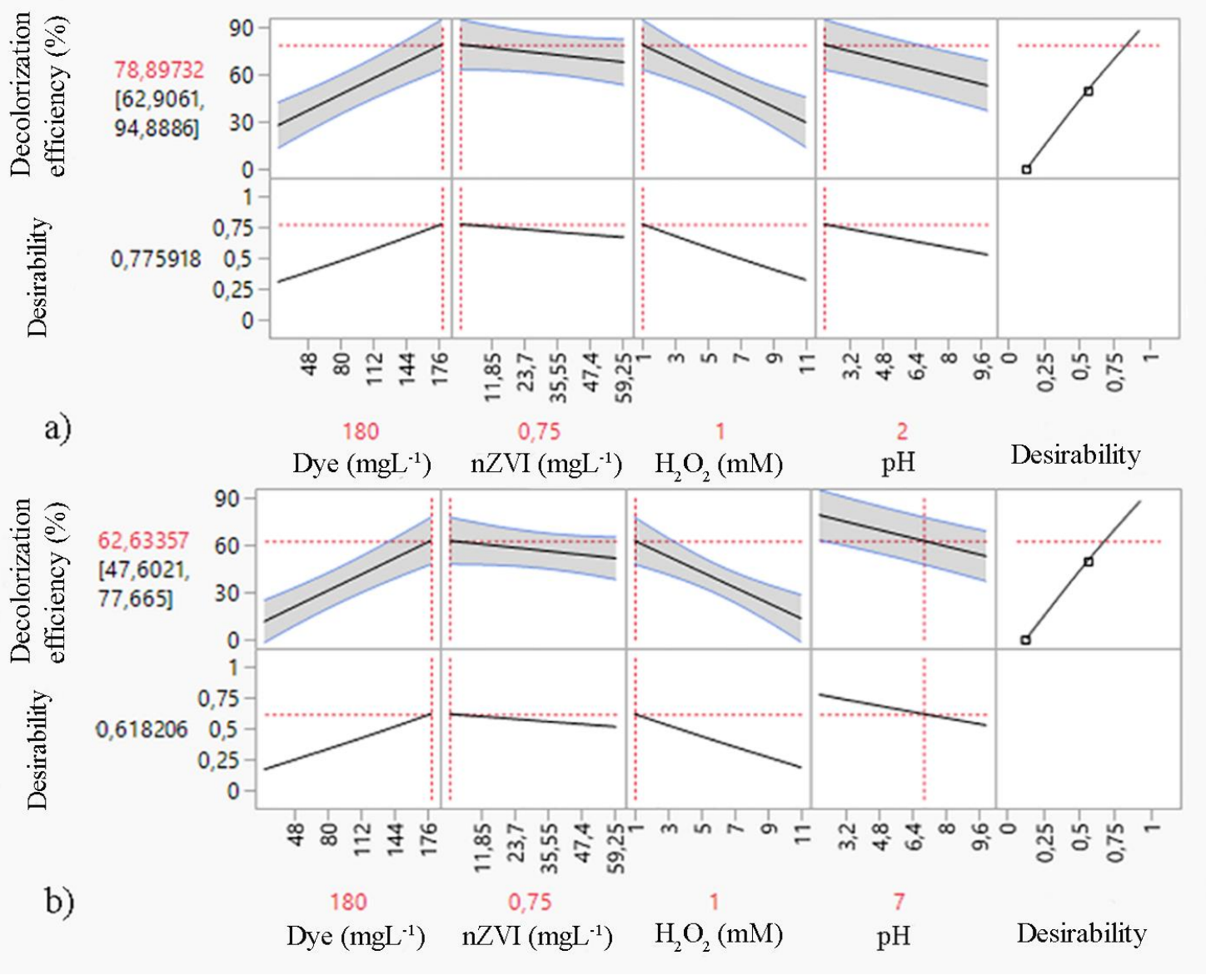

Figure 3: Optimization plot in a) acidic and b) neutral medium

The accuracy and reliability of the mathematical model can be confirmed by validation experiments. The verification of the analytically defined optimum is based on the performance of eight same experiments under the determined optimal process conditions (decolorization efficiency were: 68,25; 69.18; 69.12; $68.22 ; 69.46 ; 68.73 ; 67.96$ and $68.62 \%$ ). Based on the calculated $95 \%$ confidence interval of 68.25 $69.14 \%$ (Figure 4), it is concluded that the proposed decolorization efficiency is experimentally confirmed by verification of the selected models. 


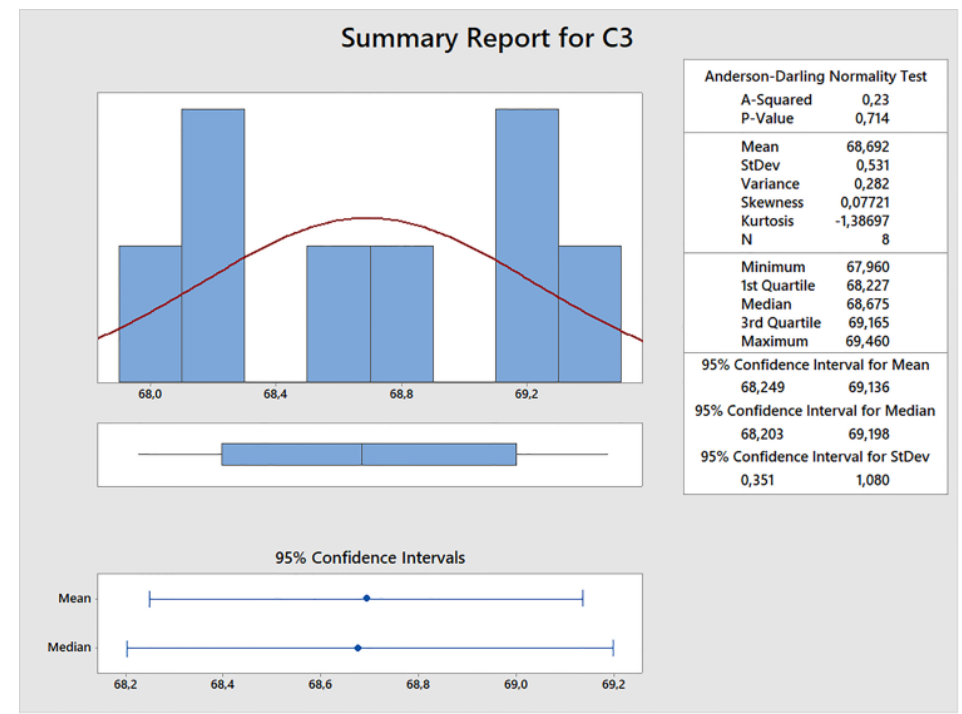

Figure 4: Verification of the optimized $n Z \mathrm{VI} / \mathrm{H}_{2} \mathrm{O}_{2}$ Fenton process

\section{CONCLUSIONS}

The aforementioned study implies that DSD is a feasible method to investigate the effect of Fenton-like process parameters on the printing dye removal efficiency with the reduction of a large number of traditional experiments. Four investigated process parameters, initial dye concentration, nanoparticles dosage, $\mathrm{H}_{2} \mathrm{O}_{2}$ concentration and $\mathrm{pH}$ value were studied using the DSD model approach. Based on the experimental results, it can be concluded that the highly effective parameters for Fenton-like process are dye concentration and $\mathrm{pH}$ value, while $\mathrm{nZVI}$ dosage had the lowest impact on printing dye removal. The optimal combination of process parameters was obtained as dye concentration of $180 \mathrm{mgL}^{-1}, \mathrm{nZVI}$ dosage of $0.75 \mathrm{mgL}^{-1}, \mathrm{H}_{2} \mathrm{O}_{2}$ concentration of $1 \mathrm{mM}$ and $\mathrm{pH}$ of 2 resulted with $79 \%$ of dye removal. The obtained results implied that Fenton-like process as environmentally friendly treatment can be used for printing dye removal from synthetic solutions. However, this study can be extended by considering real printing effluent treatment under obtained optimal process conditions, as well as its physico-chemical characterization.

\section{ACKNOWLEDGMENTS}

This research has been supported by the Ministry of Education, Science and Technological Development through the projects No. 451-03-68/2020-14/200156: "Innovative scientific and artistic research from the FTS (activity) domain" and No. 451-03-68/2020-14/ 200125.

\section{REFERENCES}

[1] Chen, X., Ji, D., Wang, X., Zang, L.: “Review on nano zerovalent iron (nZVI): from modification to environmental applications", Proceedings of IOP Conf. Series: Earth and Environmental Science (CEESD, China, 2017) 012004.

[2] Collivignarelli, M., Bertanza, G., Sordi, M., Pedrazzani, R.: "High-strength wastewater treatment in a pure oxygen thermophilic process: 11-year operation and monitoring of different plant configurations", Water Science \& Technology 71, 588-596, 2015. doi: 10.2166/wst.2015.008.

[3] Collivignarelli, M., Abba, A., Miino, M., Damiani, S.: "Treatments for color removal from wastewater: State of the art", Journal of Environmental Management 236, 727-745, 2019. doi: 10.1016/j.jenvman.2018.11.094.

[4] Felix, C., Ubando, A., Madrazo, C., Sutanto, S., Tran-Nguyen, P., Go, A., Ju, Y. Culaba, A., Chang, J., Chen, W.: "Investigation of direct biodiesel production from wet microalgae using definitive screening design", Energy Procedia 158, 1149-1154, 2019. doi: 10.1016/j.egypro.2019.01.296. 
[5] Galiano, F., Friha, I., Deowan, S., Hoinkis, J., Xiaoyun, Y., Johnson, D., Mancuso, R., Hilal, N., Gabriele, B., Sayadi, S., Figoli, A.: "Novel low-fouling membranes from lab to pilot application in textile wastewater treatment", Journal of Colloid and Interface Science 515, 208-220, 2018. doi: 10.1016/j.jcis.2018.01.009.

[6] Kecić, V. Kerkez Đ., Prica, M., Lužanin O., Bečelić-Tomin M., Tomašević Pilipović D., Dalamcija B.: "Optimization of azo printing dye removal with oak leaves-nZVI/ $\mathrm{H}_{2} \mathrm{O}_{2}$ system using statistically designed experiment", Journal of Cleaner Production 202, 65-80, 2018. doi: 10.1016/j.jclepro.2018.08.117.

[7] Kong, F., Ren, H., Pavlostathis, S., Wang, A., Nan, J., Ren, N.: "Enhanced azo dye decolorization and microbial community analysis in a stacked bioelectrochemical system", Chemical Engineering Journal 354, 351-362, 2018. doi: 10.1016/j.cej.2018.08.027.

[8] Machado, S., Pinto, S., Grosso, J., Nouws, H., Albergaria, J., Delerue-Mato C.: "Green production of zero-valent iron nanoparticles using tree leaf extracts", Science of the Total Environment 445-446, 1-8, 2013. doi: 10.1016/j.scitotenv.2012.12.033.

[9] Massoudinejad, M., Ghaderpoori, M., Azari, M.: "The removal of COD and color from textile industry by chlorine hypochlorite", International Journal of Advanced Science and Technology 76, 35-42, 2015. doi: 10.14257/ijast.2015.76.05.

[10] Maučec, D., Šuligoj, A., Ristić, A., Dražić, G., Pintar, A., Tušar, N.: "Titania versus zinc oxide nanoparticles on mesoporous silica supports as photocatalysts for removal of dyes from wastewater at neutral pH", Catalysis Today 310, 32-41, 2018. doi: 10.1016/j.cattod.2017.05.061.

[11] Meetani, M., Hisaindee, S., Abdullah, F., Ashraf, S., Rauf, M.: "Liquid chromatography tandem mass spectrometry analysis of photodegradation of a diazo compound: A mechanistic study", Chemosphere 80, 422-427, 2010. doi: 10.1016/j.chemosphere.2010.04.065.

[12] Mukherjee, R., Kumar, A., Sinha, A., Lama, Y., Saha, A.: "A review on synthesis, characterization and applications of nano-zero valent iron (nZVI) for environmental remediation", Critical Reviews in Environmental Science and Technology 46, 443-466, 2016. doi: 10.1080/10643389.2015.1103832.

[13] Natarajan, S., Bajaj, H., Tayade, R.: "Recent advances based on the synergetic effect of adsorption for removal of dyes from waste water using photocatalytic process", Journal of Environmental Sciences 65, 201-222, 2018. doi: 10.1016/j.jes.2017.03.011.

[14] Noreen, S., Bhatti, H.N., Iqbal, M., Hussain, F., Sarim, F.M.: “Chitosan, starch, polyaniline and polypyrrole biocomposite with sugarcane bagasse for the efficient removal of Acid Black dye", International Journal of Biological Macromolecules 147, 439-452, 2020. doi: 10.1016/j.ijbiomac.2019.12.257.

[15] Pirsaheb, M., Moradi, S., Shahlaei, M., Wang, X., Farhadian, N.: "A new composite of nano zerovalent iron encapsulated in carbon dots for oxidative removal of bio-refractory antibiotics from water", Journal of Cleaner Production 209, 1523-1532, 2019. doi: 10.1016/j.jclepro.2018.11.175.

[16] Ramos, R.O., Albuquerque, M.V.C., Lopes, W.S., Sousa, J.T., Leite, V.D.: "Degradation of indigo carmine by photo-Fenton, Fenton, $\mathrm{H}_{2} \mathrm{O}_{2} / \mathrm{UV}-\mathrm{C}$ and direct UV-C: Comparison of pathways, products and kinetics", Journal of Water Process Engineering 37, 101535, 2020. doi: 10.1016/j.jwpe.2020.101535.

[17] Sreeja, P.H., Sosamony, K.J.: "A Comparative Study of Homogeneous and Heterogeneous PhotoFenton Process for Textile Wastewater Treatment", Procedia Technology 24, 217-223, 2016. doi: 10.1016/j.jwpe.2020.101535. doi: 10.1016/j.protcy.2016.05.065.

[18] Sriprom, P., Krobthong, W., Assawasaengrat P.: "Investigation of important parameters for PhotoFenton degradation of methyl orange over $\mathrm{Fe} / \mathrm{TiO}_{2}$ catalyst", Proceeding of $6^{\text {th }}$ International Conference on Power and Energy Systems Engineering 2019, (CPESE, Okinawa, Japan, 2019), pages 731-736.

[19] Srinivasan, S., Sadasivam, S.: "Exploring docking and aerobic-microaerophilic biodegradation of textile azo dye by bacterial systems", Journal of Water Process Engineering 22, 180-191, 2018. doi: 10.1016/j.jwpe.2018.02.004.

[20] Tung, C., Shen, S., Chang, J., Hsu, Y., Lai, Y.: "Treatment of real printing wastewater with an electrocatalytic process", Separation and Purification Technology 117, 131-136, 2013. doi: 10.1016/j.seppur.2013.07.028.

[21] Wang, C., Zeng, W., Jiang, T., Chen, X., Zhang, X.: "Incorporating attapulgite nanorods into graphene oxide nanofiltration membranes for efficient dyes wastewater treatment", Separation and Purification Technology 214, 21-30, 2019. doi: 10.1016/j.seppur.2018.04.079. 
[22] Zhao, J., Li W., Qu, H., Tian, G., Wei, Y.: “Application of definitive screening design to quantify the effects of process parameters on key granule characteristics and optimize operating parameters in pulsed-spray fluid-bed granulation", Particuology 43, 56-65, 2019. doi: 10.1016/j.partic.2018.03.007.

[23] Zhu, Y., Xu, J., Cao, X., Cheng, Y.: "Characterization of functional microbial communities involved in different transformation stages in a full-scale printing and dyeing wastewater treatment plant", Biochemical Engineering Journal 137, 162-171, 2018. doi: 10.1016/j.bej.2018.05.026.

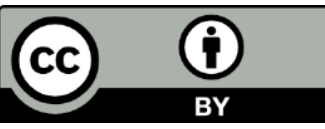

(C) 2020 Authors. Published by the University of Novi Sad, Faculty of Technical Sciences, Department of Graphic Engineering and Design. This article is an open access article distributed under the terms and conditions of the Creative Commons Attribution license 3.0 Serbia

(http://creativecommons.org/licenses/by/3.0/rs/). 